\title{
Assessing Knowledge and Attitudes Toward Spirituality in the domain of providing health care
}

Ivana Crnković*

ivana.crnkovic@zvu.hr

Ivan Brumini $* *$

ivan.brumini@zvu.hr

Aleksandar Racz***

aleksandar.racz@zvu.hr https://doi.org/10.31192/np.17.2.6

UDK/UDC: $27-584: 364.69$

303.425-057.875(497.521.2)

Izvorni znanstveni rad / Original scientific paper Primljeno/Received: 26. veljače 2019. / Feb 26, 2019 Prihvaćeno/Accepted: 4. svibnja 2019. / May 4, 2019

Theoretical starting points: Every patient has a legitimacy to receive spiritual care within their health care, while a health care professional has a responsibility and obligation to provide it. Methods: The goal of this research was to determine students' opinions on the matters of spirituality within receiving health care as well as to question the correlation between sociodemographic characteristics, and the difference between students' opinions towards the dimension of spirituality. The survey was taken by 161 students of University of Zagreb,

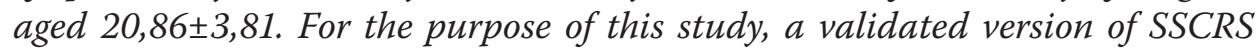
(Spirituality and spiritual care rating scale,) questionnaire was used to assess perception and opinions on spiritual care. Results: According to the results of the research students have a positive stance when it comes to the spiritual dimension, regardless of their field of study. Most of the students believe health care professionals that have completed their formal education, to be well acquainted with providing spiritual care, however, the said students included in the research had no training on the matter during their formal education. Discussion and conclusion: High quality health care requires health care professionals to be prepared both in their professional fields and the spiritual dimension, and to accommodate to this request, it is necessary to conform the curriculum to the domain of providing spiritual care.

Key words: education, health care, spirituality, SSCRS questionnaire.

* Ivana Crnković, MD, University of Applied Health Sciences Zagreb, Department of Physiotherapy; Address: Mlinarska cesta 38, HR-10000 Zagreb, Croatia.

* Ivan Brumini, MD, University of Applied Health Sciences Zagreb, Department of Anatomy and Physiology; Address: Mlinarska cesta 38, HR-10000 Zagreb, Croatia.

**** Corresponding author: Aleksandar Racz, PhD, Assist. Prof., University of Applied Health Sciences Zagreb, Department of Public Health and Health Care; Address: Mlinarska cesta 38, HR-10000 Zagreb, Croatia. 


\section{Introduction}

Spirituality is a dynamic dimension of human existence in regards to the way that people (individuals and communities) experience, express and/or search for meaning, purpose and transcendence, as well as the way that they are connected with the present moment, with themselves, others, nature, what is important and/or sacred to them. ${ }^{1}$ Today, the broad meaning of the term spirituality, both religious and nonreligious, is recognized as a resource and an important factor in many areas of human activity and their lives: in medicine, psychology, psychotherapy and counselling ${ }^{2}$, social work ${ }^{3}$, business and management world ${ }^{4}$, upbringing and education ${ }^{5}$ and many other fields ${ }^{6}$. Spirituality is a part of people as a whole. According to the holistic approach to human bodies, the mind and body are one, and every single human experience, including health and sickness, can also be interpreted as a spiritual experience. In order to get to know and provide individual support to each and every person, a model of applied health care in the field of spirituality should be accommodated and made ready so that the support can be given to the person/patient, to their religious and spiritual beliefs and needs, hence it should be defined and implemented. ${ }^{7}$ Along with the growth of civilizations of many communities and social structures, the system of providing health care has been overtaken by institution whose doctrines were based exclusively on scientific foundations and so consequently, the aspect of spiritual dimension, as well as spiritual needs despite their inseparability as a part of a healthy and sick person's character, have been disregarded. By intensifying the holistic approach, the focus has once again been returned to spirituality as a part of people's nature. By developing the holistic approach and the idea itself $f^{8}$, simultaneously within the

${ }^{1}$ V. BEŠLIĆ, Duhovnost i duhovnik u palijativnoj skrbi, Nova prisutnost, 15 (2017) 1, 89-99, 92; https://doi.org/10.31192/np.15.1.5.

2 C.R. CLONINGER, Spirituality and the Science of Feeling Good, Southern Medical Journal, 100 (2007) 7, 740-743, 740; doi: 10.1097/SMJ.0b013e318070d177; http://sma.org/southernmedical-journal/article/spirituality-and-the-science-of-feeling-good/.

${ }^{3}$ I. LEUTAR, Z. LEUTAR, Duhovnost kao resurs snage i otpornosti obitelji u rizičnim okolnostima, Nova prisutnost, 15 (2017) 1, 65-87, 65; https://doi.org/10.31192/np.15.1.4.

${ }^{4}$ I. KOPREK, Management i duhovnost, Obnovljeni život, 59 (2004) 4, 469-474, 469; https:// hrcak.srce.hr/1171.

${ }^{5}$ T.A. FILIPOVIĆ, Vjeronauk i promicanje duhovnog razvoja učenika u ozračju novog interesa za duhovnost, Radovi Zavoda za znanstvenoistraživački i umjetnički rad u Bjelovaru, 11 (2017) 127-142, 134; https://doi.org/10.21857/yq32oh46g9.

${ }^{6}$ D. ZOHAR, I. MARSHALL, Is It Still Capitalism in: Spiritual Capital: Wealth We Can Live By, San Francisco, Berrett-Koehler Publishers, 2004, 147. https://www.bkconnection.com/static/ Spiritual_Capital_EXCERPT.pdf (01.02.2019).

7 W. MCSHERRY, RCN spirituality survey 2010. A report by the Royal College of Nursing on members' views on spirituality and spiritual care in nursing practice, London, Royal College of Nursing, 2011, 16-19; https://www.merseycare.nhs.uk/media/1863/rcn-spirituality-survey.pdf (26.02.2019).

${ }^{8}$ McSherry, ibid., 19. 
medical field, spiritual care has become a widespread and legitimate activity in the profession of a health care professionals?

According to the Law of Medical Protection in the Republic of Croatia, medical attention is conducted in accordance with the principles of universality, continuity, availability and complete access to primary medical protection, specialized approach within special-conciliar and hospital medical attention, and in accordance with the principles of subsidiary and functional integration. ${ }^{10}$ Led by a principle of universality of medical care, the right to spirituality is guaranteed by the Law, and still none of its implementations within medical establishments are regulated, as well as the way they are provided within the educational system is not regulated.

People are spiritual beings and thus every patient has a right to receive spiritual care that can also be refused, but that is why the responsibility lays on every health care professional to inform the patient and provide him with the said possibility of spiritual attention. Only a small number of Croatian researches focus on the dimension of spirituality, especially on students population, so the goals of this study were to determine the opinions of students on the matters of spirituality within providing health care, as well as to question the correlation between sociodemographic characteristics and the difference between students' opinions towards the dimension of spirituality.

\section{Design, data and methods}

\subsection{Sample description}

The study included 161 students, aged 20,86 $\pm 3,81$ (Mean $=20.857, \mathrm{SD}=3.8126$ ). Undergraduate and graduate students from first to fifth year study programs of University of Zagreb were included in the study, along with the students of integrated undergraduate and graduate studies (see Table 1 and 2).

In this research, the field of Economic sciences is abstracted as separate from the field of Social sciences due to the specificity of the study's question. In all the groups that were questioned for the purpose of this study, we can find a much larger share or female participants (82.6\%) in comparison to male participants (17.4\%).

\footnotetext{
9 W. McSHERRY, P. DRAPER, D. KENDRICK, Construct Validity of a Rating Scale Designed to Assess Spirituality and Spiritual Care, International Journal of Nursing Studies, 39 (2002) 7, 723-734, 723; https://www.ncbi.nlm.nih.gov/pubmed/12231029.

${ }^{10}$ ZAKON O ZDRAVSTVENOJ ZAŠTITI, Narodne novine 100/18; https://narodne-novine. nn.hr/clanci/sluzbeni/2018_11_100_1929.html (26.02.2019).
} 
Table 1. Division of participants by major of study

\begin{tabular}{|l|c|c|}
\hline & $\mathbf{N}$ & $\mathbf{\%}$ \\
\hline 1. Social sciences & 17 & 10.6 \\
\hline 2. Health sciences & 87 & 54.0 \\
\hline 3. Economy & 8 & 5.0 \\
\hline 4. Humanities & 42 & 26.1 \\
\hline 5. Techinical sciences & 7 & 4.3 \\
\hline Total & 161 & 100 \\
\hline
\end{tabular}

Table 2. Division of participants by year of study

\begin{tabular}{|l|c|c|}
\hline & N & \% \\
\hline Year 1 & 54 & 33.5 \\
\hline Year 2 & 96 & 59.6 \\
\hline Year 3 & 8 & 5.0 \\
\hline Year 4 & 1 & 0.6 \\
\hline Year 5 & 2 & 1.2 \\
\hline Total & 161 & 100 \\
\hline
\end{tabular}

\subsection{Measuring instrument}

For the purpose of this study a SSCRS questionnaire has been used (Spirituality and spiritual care rating scale).${ }^{11}$ SSCRS is an instrument that has shown consistent reliability and quality in determining the perception and stance towards spirituality and spiritual care. ${ }^{12}$ The SSCRS questionnaire consists of 33 statements separated into three domains. The first domain of the SSCRS questionnaire consists of questions about: sex, age, the level of qualification/ education, the duration of work hours, the nature of work hours, the duration of work experience and affiliation with any kind of specialized health care. The second domain of the SSCRS questionnaire has 14 statements through the Likert's scale of five points in regards to: perception of spirituality in nine specific fields (hope; meaning and purpose of life; forgiveness; beliefs; spiritual care; relationships; faith in God; behavior and moral; and expression). The third domain of the SSCRS questionnaire consists of questions about determining and applying spiritual care: educational opportunities; the role of legislature and institutions of regulation and possible connection and influence of personalized spirituality of a health care professional on spiritual care. The gross results show a generally positive stance towards spirituality. A validated Croatian version of the SSCRS questionnaire has been used for this study.

\subsection{Data Collection and Analysis}

Data collection process began with a request for the approval of the research according to the decision of the Commission for Academic Issues and the research team also asked for the permission for use the SSCRS questionnaire. The survey was carried out from the beginning of August 2018 to January 2019. The researcher came in touch with the participants and asked them to participate in the research after explaining the nature and the scope of the

\footnotetext{
${ }^{11}$ McSherry, ibid., 32-37.

${ }^{12}$ McSherry, Draper, Kendrick, ibid., 723.
} 
study. Data were collected using the snowball method, i.e. the participants who agreed to participate in the online survey were asked to send this questionnaire to their colleagues in their study year. The guidelines and informed consent were at the beginning of the survey. The entire procedure was anonymous, and each participant had the right to withdraw from the research at any time. Data processing used descriptive statistics (mean, range, minimum, maximum, standard deviation). Within the group and between the group's differences were analyzed by parametric (t-test). SPSS Statistics 17.0 software was used for statistical analyses.

\section{Results}

If the whole sample of representatives is to be observed, the majority of students believe health care professionals to be capable of providing spiritual care through the visit of a priest/spiritual leader, as well as through empathy and time spent with the patient. They do not consider the dimension of spirituality to be connected with religion and visiting a church, nor with religious beliefs. According to the results in Table 3, students relate spirituality with morale, forgiveness, hope and positive and negative experiences in life.

Table 3. Students' opinions on the dimension of spirituality within providing health care.

\begin{tabular}{|l|c|c|}
\hline & Mean & \pm SD \\
\hline $\begin{array}{l}\text { I believe that health care professionals can provide spiritual care to a } \\
\text { patient by organizing a visit from a priest/pastor or patients personal } \\
\text { spiritual leader. }\end{array}$ & 3.91 & 1.29 \\
\hline $\begin{array}{l}\text { I believe that health care professionals can provide spiritual care by } \\
\text { showing kindness, support and cheerfulness while providing their care. }\end{array}$ & 4.41 & 1.04 \\
\hline $\begin{array}{l}\text { I believe that spirituality is connected to forgiveness and the need to be } \\
\text { forgiven. }\end{array}$ & 4.03 & 1.14 \\
\hline $\begin{array}{l}\text { I believe that spirituality means solely going to church or the place or } \\
\text { religious rituals. }\end{array}$ & 1.76 & 1.16 \\
\hline $\begin{array}{l}\text { I believe that spirituality is not connected with faith in God or a higher } \\
\text { being. }\end{array}$ & 2.57 & 1.4 \\
\hline $\begin{array}{l}\text { I believe that spirituality is finding the meaning of positive and negative } \\
\text { experiences in life. }\end{array}$ & 3.61 & 1.23 \\
\hline $\begin{array}{l}\text { I believe that a health care professional can provide spiritual care by } \\
\text { spending time with a patient, giving them hope, especially in the time of } \\
\text { need. }\end{array}$ & 4.12 & 1.08 \\
\hline $\begin{array}{l}\text { I believe that a health care professional can provide spiritual care by helping } \\
\text { the patient find meaning and purpose in their illness. }\end{array}$ & 3.84 & 1.21 \\
\hline I believe that the purpose of spirituality is to find a sense of hope in life. & 3.89 & 1.12 \\
\hline $\begin{array}{l}\text { I believe that spirituality is connected to the way people govern their lives } \\
\text { here and now. }\end{array}$ & 3.82 & 1.09 \\
\hline
\end{tabular}




\begin{tabular}{|l|c|c|}
\hline $\begin{array}{l}\text { I believe that a health care professional can provide spiritual care by } \\
\text { listening to the patient and giving them time to discuss and look into their } \\
\text { fears, anxieties and worries. }\end{array}$ & 4.04 & 1.08 \\
\hline $\begin{array}{l}\text { I believe that spirituality is a unifying force that enables people to be in } \\
\text { peace with themselves and the rest of the world. }\end{array}$ & 4.08 & 1.07 \\
\hline $\begin{array}{l}\text { I believe that spirituality does not consists of fields such as art, creativity } \\
\text { and personalized expression. }\end{array}$ & 2.43 & 1.29 \\
\hline $\begin{array}{l}\text { I believe that a health care professional can provide spiritual care to a } \\
\text { patient by respecting their privacy dignity and religious and cultural beliefs. }\end{array}$ & 4.23 & 1.08 \\
\hline I believe that spirituality includes personal friendships and relationships. & 4 & 1.12 \\
\hline I believe that spirituality does not include atheists and agnostics. & 2.37 & 1.38 \\
\hline I believe that spirituality includes human morale. & 4.06 & 1.15 \\
\hline
\end{tabular}

According to the results shown in Table 4, 32.9\% of students have thus far been confronted by a patient with spiritual needs, $70.8 \%$ of students do not consider themselves to be educated for determining the spiritual needs of their patients but the majority of them had received no education in spiritual care during their formal education. A similar stance is taken by students who believe health care professionals have not received sufficient training in regards to spiritual care. When it comes to responsibility, $50.9 \%$ of students thinks that the whole team should be in charge for providing spiritual attention.

Table 4. The dimension of spiritual care in regards to education.

\begin{tabular}{|l|c|c|}
\hline \multirow{2}{*}{$\begin{array}{l}\text { Have you ever been practically confronted by a patient with } \\
\text { spiritual needs? }\end{array}$} & 67.1 & 32.9 \\
\hline $\begin{array}{l}\text { Do you consider yourself to be capable and educated enough to } \\
\text { determine spiritual needs of your patients? }\end{array}$ & 70.8 & 24.8 \\
\hline $\begin{array}{l}\text { Have you had any training on spiritual care during your formal } \\
\text { education? }\end{array}$ & 65.8 & 31.1 \\
\hline $\begin{array}{l}\text { Do you think that health care professionals receive enough training } \\
\text { in spiritual care? }\end{array}$ & 81.4 & 13.7 \\
\hline Are you a part of a religious group? & 30.4 & 69.6 \\
\hline
\end{tabular}

During the analysis of the difference in results between the SSCRS questionnaire and the analyzed frequencies, as well as the gross result among the representative groups, an independent t-test has been used. Depending on the sex of the participant, there is a statistically significant difference in regards to the questions: »Have you ever been practically confronted by a patient with spiritual needs?» and »Do you think that health care professionals receive enough training in spiritual care? « There were no other statistically significant differences between sexes among other questions (see Table 5). 
Table 5. The differences between analyzed groups in regards to sex.

\begin{tabular}{|c|c|c|c|c|c|}
\hline SEX & & $\mathbf{M}$ & $\mathbf{F}$ & $\begin{array}{c}\text { chi- } \\
\text { square }\end{array}$ & $\mathbf{p}$ \\
\hline \multirow{2}{*}{$\begin{array}{l}\text { Have you ever been practically confronted by a } \\
\text { patient with spiritual needs? }\end{array}$} & $\mathrm{NO}$ & 14 & 94 & \multirow{2}{*}{4.478} & \multirow{2}{*}{$0.034^{*}$} \\
\hline & YES & 14 & 39 & & \\
\hline \multirow{2}{*}{$\begin{array}{l}\text { Do you consider yourself to be capable and } \\
\text { educated enough to determine spiritual needs of } \\
\text { your patients? }\end{array}$} & $\mathrm{NO}$ & 17 & 97 & \multirow{2}{*}{2.084} & \multirow{2}{*}{0.149} \\
\hline & YES & 10 & 30 & & \\
\hline \multirow{2}{*}{$\begin{array}{l}\text { Have you had any training on spiritual care during } \\
\text { your formal education? }\end{array}$} & $\mathrm{NO}$ & 20 & 86 & \multirow{2}{*}{0.563} & \multirow{2}{*}{0.453} \\
\hline & YES & 7 & 43 & & \\
\hline \multirow{2}{*}{$\begin{array}{l}\text { Do you think that health care professionals receive } \\
\text { enough training in spiritual care? }\end{array}$} & $\mathrm{NO}$ & 19 & 112 & \multirow{2}{*}{6.194} & \multirow{2}{*}{$0.013^{*}$} \\
\hline & YES & 8 & 14 & & \\
\hline \multirow{2}{*}{ Are you a part of a religious group? } & $\mathrm{NO}$ & 11 & 38 & \multirow{2}{*}{1.254} & \multirow{2}{*}{0.263} \\
\hline & YES & 17 & 95 & & \\
\hline
\end{tabular}

From the results shown in Table 6 there is a statistically significant difference in regards to the question: »Have you ever been practically confronted by a patient with spiritual needs«, while there are no other statistically significant differences depending on the major of the student.

Table 6. Differences between analyzed groups in regards to the students' majors.

\begin{tabular}{|c|c|c|c|c|c|c|c|c|}
\hline UNIVERSIRY MAJOR & & 1 & 2 & 3 & 4 & 5 & $\begin{array}{c}\text { chi- } \\
\text { square }\end{array}$ & $\mathbf{p}$ \\
\hline \multirow{2}{*}{$\begin{array}{l}\text { Have you ever been practically } \\
\text { confronted by a patient with spiritual } \\
\text { needs? }\end{array}$} & NO & 16 & 61 & 7 & 20 & 4 & \multirow{2}{*}{15.018} & \multirow{2}{*}{$0.005^{*}$} \\
\hline & YES & 1 & 26 & 1 & 22 & 3 & & \\
\hline \multirow{2}{*}{$\begin{array}{l}\text { Do you consider yourself to be capable } \\
\text { and educated enough to determine } \\
\text { spiritual needs of your patients? }\end{array}$} & $\mathrm{NO}$ & 11 & 68 & 6 & 24 & 5 & \multirow{2}{*}{7.843} & \multirow{2}{*}{0.097} \\
\hline & YES & 4 & 15 & 2 & 17 & 2 & & \\
\hline \multirow{2}{*}{$\begin{array}{l}\text { Have you had any training on spiritual } \\
\text { care during your formal education? }\end{array}$} & $\mathrm{NO}$ & 13 & 59 & 5 & 24 & 5 & \multirow{2}{*}{4.312} & \multirow{2}{*}{0.365} \\
\hline & YES & 2 & 26 & 3 & 17 & 2 & & \\
\hline \multirow{2}{*}{$\begin{array}{l}\text { Do you think that health care } \\
\text { professionals receive enough training in } \\
\text { spiritual care? }\end{array}$} & $\mathrm{NO}$ & 14 & 75 & 6 & 32 & 4 & \multirow{2}{*}{8.61} & \multirow{2}{*}{0.072} \\
\hline & YES & 1 & 8 & 2 & 8 & 3 & & \\
\hline \multirow{2}{*}{ Are you a part of a religious group? } & $\mathrm{NO}$ & 2 & 29 & 4 & 11 & 3 & \multirow{2}{*}{5.458} & \multirow{2}{*}{0.243} \\
\hline & YES & 15 & 58 & 4 & 31 & 4 & & \\
\hline
\end{tabular}

1. Social sciences; 2 . Health sciences; 3 . Economy; 4. Humanities; 5 . Technical sciences. 


\section{Discussion}

The concept of spirituality is found in all cultures and societies. It is expressed in an individual's search for ultimate meaning through participation in religion and/or belief in God, family, naturalism, rationalism, humanism, and the arts. All of these factors can influence how patients and health care professionals perceive health and illness and how they interact with one another. ${ }^{13}$ The differences between the spiritual dimension and science have had significant consequences to the world we live in, which have also reached its peak in the culture of the $20^{\text {th }}$ century that is based on mechanical understanding of reality. One of the biggest victims of this breach is none other than medicine where spirituality has lost its important place due to a limiting perception of people as machines. In the $21^{\text {st }}$ century the dimension of spirituality has once again started to regain its legitimacy within medical community. ${ }^{14}$ The definition of health, according to the World Health Organization, is a state of complete physical, spiritual and social content, not only the absence of sickness and exhaustion. Thanks to the holistic approach to medicine and rehabilitation, spiritual care has become a legitimate part of every patient's recovery. Today, the holistic approach is again encouraged in clinical treatments. It stems from the viewpoint that in order to fully comprehend health and sickness, one must not only study people as individuals, but also as complex systems that are permanently interacting with their social and physical environment ${ }^{15}$.

By going deeper into the history of medicine itself and of care for patients, we notice that such a profession has arisen from the family. Everything was happening with those closest to us, from birth to caring for elders. In such a way, treatments were not simply reduced to science that was undoubtedly not yet as developed at that time, but the treatments themselves carried a degree of responsibility, respect and love towards another person. With such intentions, every member of the family was invited to treat and to help with the healing process. Even though such occurrences are today attributed to primitive societies where spiritual care often involved paganism, witchcraft and many other superstitions, since the appearance of Christendom and other similar religions, we notice a social action for all those in need. It may not seem as spiritual aid

${ }^{13}$ C. M. PUCHALSKI, The role of spirituality in health care, Bumc Proceedings, 14 (2001) 4, 352357, 356; https://www.ncbi.nlm.nih.gov/pmc/articles/PMC1305900/ (01.02.2019).

${ }^{14}$ B. BLAŽINIĆ, Duhovnost $i$ kronične psihosomatske bolesti, Zagreb, IQ - Institut za kvalitetu i razvoj ljudskih potencijala, 2-3; http://udruzenjemultiplesklerozecrnegore.com/wpcontent/uploads/2018/09/07_duhovnost_i_hronic_ne_psihosomatske_bolesti-converted.pdf (01.02.2019).

${ }^{15}$ M. E. O'BRIEN, Spiritual Care: Nurses Role. Spirituality in Nursing, Standing on Holy Ground, Sudbury, Jones \& Bartlett Learning, 2011, 9; https://books.google.hr/books?hl=hr\&lr=\&id=GQIDgAAQBAJ\&oi=fnd\&pg=PR1\&ots=FLjPOXupdE\&sig=qoJQm1KwsCUXworBEpSJYLzWq _I\&redir_esc $=\mathrm{y} \# \mathrm{v}=$ onepage\&q\&f$=$ false $(11.02 .2019)$. 
due to the fact it has been provided on a primarily physical level, but the wellknown development of nursing has its foundations in the spiritual movement of monasticism and within that, it carries a desire for healing, both of the body and soul.

The spiritual environment was actually the environment for healing and caring for patients. With that in mind, it can be concluded that today's behavior of health care professionals should include a spiritual component from which it has grown. Many spiritual trends and movements, the society itself, modern psychology, as well as the whole definition of health point to that fact. The Nursing and Midwifery Council (NMC) in the United Kingdom in line with the European Qualifications Framework (EQF) defines competence as »the proven ability to use knowledge, skills and personal, social and/or methodological abilities in the work or study situations and in professional and personal development« referred to as »responsibility and autonomy«. The three core domains of competences for spiritual care namely, awareness and use of self; spiritual dimensions of the nursing process (assessment, planning, implementation and evaluation of care); and assurance and quality expertise. ${ }^{16}$ The said example of good practice in the domain of educating nurses cannot be found within the education of other medial professionals that make up a medical team.

According to literature review the insufficient representation of spiritual dimension, as a focus of study, during the education of health care professionals, has shown a major barrier in conducting health care. According to results provided in this study, the majority of students believe health care professionals to be acquainted with providing spiritual attention by the end of their formal education, however most of the students who took part in the research had no education in spiritual care during their formal education. It is imperative that Universities that provide education for health professionals, should pay special attention to human health, the values and beliefs of patients, families and society and provide holistic care based on inter-professional education. ${ }^{17}$ The overall sample of students included in the study, do not associate the spiritual dimension with visiting a church, nor with religious affiliations, hence they equate spirituality with morale, forgiveness, hope and positive and negative experiences in life. Research has shown that the strongest predictor for effective

${ }^{16}$ D. R. BALDACCHINO, Spiritual Care Education of Health Care Professionals, Religions, 6 (2015) 2, 594-613, 596; doi:10.3390/rel6020594; https://www.researchgate.net/publication/276452606_Spiritual_Care_Education_of_Health_Care_Professionals; THE EUROPEAN QUALIFICATIONS FRAMEWORK FOR LIFELONG LEARNING, Belgium: European Commission Press, 2008, 11; http://ecompetences.eu/wp-content/uploads/2013/11/EQF_ broch_2008_en.pdf (21.02.2019).

${ }^{17}$ M. ASADZĀNDI, Z. VAFADAR, Designing Inter Professional Spiritual Health Care Education Program for Students of Health Sciences, Journal of Nursing and Patient Health Care, 1 (2018) 1, 1-7, 5; http://www.annexpublishers.com/articles/JNPHC/1101-Designing-InterProfessional-Spiritual-Health-Care-Education-Program-for-Students-of-Health-Sciences.pdf (26.02.2019). 
spiritual care is personal spirituality. No one can give from what he/she does not possess. This indicates the importance of maintaining the integrity between the individual person and the role of health care professionals to address and meet patients' needs holistically. Therefore, health care professionals can both provide spiritual care and can also provide care spiritually. Since, competence in professional practice incorporates knowledge, skills and attitudes with achievable outcomes, additional to knowledge, the active presence of the health care professional, that is being in doing, not simply doing, is needed to meet patients' spiritual needs and to generate the holistic doing of spiritual care. ${ }^{18}$

Depending on the sex of the participant, there is a statistically significant difference in regards to the questions: »Have you ever been practically confronted by a patient with spiritual needs?« and »Do you think that health care professionals receive enough training in spiritual care? « Such a result can be explained with a fact that in our research sample, the ratio of male and female representatives is not equal, and there is sex difference that can be found in different fields of the study. Within humanity sciences, biomedicine and medicine, as well as within social sciences, the majority of the students are female while technical sciences are mostly enrolled by male students. The result can also be explained by a fact that female students in the questioned domain have more experience than the male representatives. The results of this study show there is a statistically significant difference in regards to the question: »Have you ever been practically confronted by a patient with spiritual needs«, while there are no other statistically significant differences depending on the major of the student. During the course of their education, the students of medical majors gain clinical and practical experience within courses like Clinical Practices in different medical establishments where they have a chance to encounter patients that have a need for spiritual care, on the contrary to students of other majoring fields. Such a form of experience is valuable to medical students and their work within a medical team, as well as an opportunity upon finishing their education where the education of providing spiritual attention can be conducted, and be a part of the outcomes when learning such courses.

\section{Conclusions}

In accordance with the goals set in this research, the students have a positive stance towards spirituality regardless of their major. The sample of students that took part in the study gives relevancy to all statistical procedures conducted on the results, even though the generalization of the results provided with this study is only limited to the students of the University of Zagreb.

${ }^{18}$ Baldacchino, ibid., 597. 
According to the results provided by this study, majority of the students consider medical professionals to be acquainted with providing spiritual attention upon completing their education, but at the same time most of the students have had no education on spiritual care during their formal education. This study provides guidelines for future research focused on the perception of spirituality, as well as the integration of spirituality within health care through a college curriculum. In future studies, an opinion of health care professionals on spirituality within providing health care should be determined. Due to the lack of professional literature, longitudinal studies should be conducted that would explore the relationship between the spiritual dimension and health care over a longer period of time.

\section{Acknowledgements}

We would like to express our great appreciation to Pio Buzov (University of Zagreb, Faculty of Philosophy and Religious Studies, Jordanovac 110, Croatia) for his valuable and constructive suggestions during the planning and development of this research work. His willingness to give his time so generously has been very much appreciated. This research was supported by the Scientific Research Grant from University of Applied Health Sciences - 2018. 


\section{Ivana Crnković" - Ivan Brumini*** - Aleksandar Racz"**** \\ Procjena znanja i stavova prema duhovnosti u domeni pružanja zdravstvene skrbi}

\section{Sažetak}

Teorijska polazišta: Legitimitet na duhovnu skrb ima svaki pacijent u okviru zdravstvene zaštite, a zdravstveni djelatnik obvezu njezina pružanja i odgovornost za nju. Metode: Cilj istraživanja bio je: utvrditi stavove studenata prema duhovnosti u pružanju zdravstvene skrbi te ispitati povezanost sociodemografskih karakteristika i razlike u stavovima studenata prema dimenziji duhovnosti. U istraživanju je sudjelovao 161 student Sveučilišta u Zagrebu u dobi od $20,86 \pm 3,81$. Za svrhe ovog istraživanja korištena je validirana verzija SSCRS upitnika (Spirituality and spiritual care rating scale) za procjenu percepcije i stavova duhovne skrbi. Rezultati: Prema dobivenim rezultatima istraživanja studenti, neovisno o smjeru studija, imaju pozitivne stavove prema dimenziji duhovnosti. Većina studenata smatra da su zdravstveni djelatnici nakon završetka formalnog obrazovanja upoznati s pružanjem duhovne skrbi no istovremeno studenti obuhvaćeni ovim istraživanjem nisu imali nikakvu edukaciju o duhovnoj skrbi za vrijeme svog formalnog obrazovanja. Rasprava i zaključak: Kvalitetna zdravstvena skrb pacijenta zahtijeva pripremljenost zdravstvenog djelatnika kako u stručnosti tako i u duhovnosti. Da bi se odgovorilo na ovaj zahtjev potrebno je prilagoditi sadržaj nastavnog kurikuluma u domeni pružanja duhovne skrbi.

Ključne riječi: duhovnost, obrazovanje, SSCRS upitnika, zdravstvena skrb.

* Ivana Crnković, mag. physioth., Zdravstveno veleučilište Zagreb, Katedra za fizioterapiju; Adresa: Mlinarska cesta 38, HR-10000 Zagreb; E-mail: ivana.crnkovic@zvu.hr.

** Ivan Brumini, dr. med., Zdravstveno veleučilište Zagreb, Katedra za anatomiju i fiziologiju; Adresa: Mlinarska cesta 38, HR-10000 Zagreb; E-mail: ivan.brumini@zvu.hr.

*** Autor za korespondenciju: doc. dr. sc. Aleksandar Racz, Zdravstveno veleučilište Zagreb, Katedra za javno zdravstvo i zdravstvenu zaštitu; Adresa: Mlinarska cesta 38, HR-10000 Zagreb; E-mail: aleksandar.racz@zvu.hr. 